\title{
Upaya Meningkatkan Aktifits dan Hasil Belajar PAI Peserta Didik kelas V Semester dua Tahun pelajaran 2018/2019 Melalui Penerapan Model STAD Di SD Negeri 47 Cakranegara
}

\author{
Sriulan, S.Pd.I., M.Pd.I \\ Guru Kelas V SD Negeri 47 Cakranegara
}

\begin{abstract}
Penelitian ini bertujuan untuk mengetahui efektifitas penerapan model STAD dalam upaya meningkatkan aktifitasdan hasil belajar Matematika Peserta didik kelas V SD Negeri 47 Cakranegara. Manfaat penelitian ini adalah sebagai bahan kajian dan bahan temuan dalam pelaksanaan proses pembelajaran di kelas senyatanya. Bagi guru untuk meningkatkan kompetensi dalam proses pembelajaran dan bagi peserta didik untuk meningktakan aktifitas dan hasil belajar peserta didik. Penelitian ini dilaksanakan dua siklus, masing-masing siklus kegiatannya adalah; perencanaan, pelaksanaan, observasi dan refleksi. Hasil akhir tindakan pada siklus II menunjukkan bahwa hasil observasi guru memperoleh skor rata-rata $(4,47)$ dan hasil observasi peserta didik mencapai skor rata-rata $(4,55)$. Sedangkan hasil belajar peserta didik adalah mencapai nilai rata-rata $(81,50)$, artinya indikator keberhasilan $(\geq 75,00)$ telah terlampaui. Karena indikator keberhasilan telah terbukti penelitian dinyatakan berhasil dan dihentikan pada siklus II.
\end{abstract}

Kata Kunci : Aktifitas, hasil Belajar, Penerapan Model STAD

\section{PENDAHULUAN}

Dewasa ini pola pembelajaran di tingkat sekolah dasar (SD) secara umum masih cenderung di dominasi oleh guru kelas/guru bidang studi. Peserta didik tak ubahnya seperti teori "tabula rasa". yaitu suatu proses pembelajaran yang mengarah ke guru sentris dimana peserta didik dianggap seperti kertas putih bersih yang belum ditulis/dicoret dengan tinta. Selama proses pembelajaran, guru berapi-api ceramah dengan suara lantang yang penuh semangat menjelaskan materi pelajaran. Sementara peserta didik duduk manis mendengarkan penjelasan guru dan mencatat apa saja yang diminta oleh guru di kelas, tahu atau tidak tahu yang penting patuh dan taat apa yang menjadi perintah guru kelasnya, guru bertindah sebagai raja kecil yang menguasai kelas dan selama proses pembelajaran di kelas senyatanya.

Proses pembelajaran yang mengarah ke guru sentris akan berdampak terhadap cara belajar peserta didik. Pola ini biasanya peserta didik cenderung pasif, tidak mendengarkan penjelasan guru karena merasa bosan dengan pola ceramah melulu, di kelas ada peserta didik membicarakan sesuatu yang tidak ada hubungannya dengan pelajaran, ada anak yang tidur lelap selama proses pembelajaran, yang lebih parah lagi ada anak yang keluar masuk tanpa seijin guru kelas, main lemparlemparan, main HP, dan tidak mengerjakan tugas yang diberikan oleh guru kelasnya. Akibatnya proses pembelajaran menjadi tidak bermakna, kriteria ketuntasan minimal (KKM) tidak dapat tercapai dan pelaksanaan perbaikan pembelajaran pun juga tidak bermakna.

Proses pembelajaran di kelas V SD Negeri 47 Cakranegara khususnya pada mata pelajaran Pendidikan Agama Islam dapat dipaparkan sebagai berikut: 1) ada yang tidak mendengarkan penjelasan guru, 2) tidak mau mengerjakan tugas, 3) ribut/bermain-main yang tidak ada hubungannya dengan mata pelajaran Pendidikan Agama Islam, 4) keluar masuk kelas tanpa ijin dengan alasan meludah, mau ke kamar mandi dan alasan lain yang tidak masuk akal.

Rendahnya aktivitas dan hasil belajar Pendidikan Agama Islam peserta didik kelas V SD Negeri 47 Cakranegara disebabkan karena : 1) guru mengajar hanya ceramah dan pemberian tugas yang jarang dikontrol (diawasi), 2) peserta didik kurang teraktivitas untuk belajar karena hanya guru saja yang aktif berbicaradari awal sampai akhir pelajaran, 3) peserta didik banyak yang tidak mau mengerjakan tugas/soal yang diberikan oleh guru karena kurang memahami materi pelajaran, 4) standar krikteria ketuntasan 
minimal (KKM) terlalu tinggi untuk ukuran mata pelajaran Pendidikan Agama Islam, dan yang ke 5) hubungan individu antara guru dengan peserta didik kurang terjalin sehingga peserta didik terkesan takut dengan guru yang mengakibatkan aktivitas dan hasil belajar rendah.

Banyak solusi yang bisa dilakukan oleh peneliti diantaranya yaitu dengan menerapkan pendekatan pembelajaran Cooperative Learning (CL). Model pembelajaran ini Peserta didik belajar dengan membentuk kelompok kecil. Di dalam kelompok itu Peserta didik dapat saling asah, saling asuh dalam memecahkan permasalahan yang diberikan oleh guru. Pendekatan Cooperative Learning banyak macamnya, diantaranya adalah model pembelajaran tipe STAD (Student Teams Archivement Divisions). Model pembelajaran tipe STAD ini terdiri dari lima komponen utama, yaitu, presentasi kelas, tim, kuis, skor kemajuan individu dan rekognisi tim. Dengan model pembelajaran tipe STAD diharapkan motivasi dan hasil belajar dari Peserta didik Kelas VIB di SD Negeri 47 Cakranegara dapat ditingkatkan.

Untuk membuktikan beberapa keunggulan Model pembelajaran tipe STAD ini maka perlu diadakan Penelitian Tindakan Kelas (PTK) dengan judul “ Upaya Meningkatkan Aktifits dan Hasil Belajar PAI Peserta Didik kelas V Semester dua Tahun pelajaran 2018/2019Melalui Penerapan Model STAD Di SD Negeri 47 Cakranegara".

\section{Rumusan Masalah}

"Apakah penerapan model STAD dapat meningkatkan aktivitas dan hasil belajar Pendidikan Agama Islam peserta didik kelas VSD Negeri 47 Cakranegara semester dua tahun pelajaran 2018/2019?

\section{Tujuan Penelitian}

"Untuk mengetahui efektifitas penerapan Model STAD dalam upaya meningkatkan aktivitas dan hasil belajar Pendidikan Agama Islam peserta didik kelas VSD Negeri 47 Cakranegara Semester dua tahun pelajaran 2018/2019”.

\section{Manfaat Penelitian}

a. Bermanfaat bagi guru selaku peneliti dalam rangka melaksanakan proses pembelajaran yang kontekstual melalui penerapan Model STAD di kelas senyatanya serta dalam upaya perwujudan pembelajaran yang aktif, inovatif, kreatif, efektif, dan menyenangkan (PAIKEM) sehingga aktivitas dan hasil belajar peserta didik dapat ditingkatkan.

b. Bermanfaat bagi peserta didik dalam upaya meningkatkan prestasi belajar peserta didik.

\section{KAJIAN PUSTAKA \\ Aktivitas Belajar}

Aktivitas belajar adalah aktivitas yang bersifat fisik maupun mental. Dalam proses belajar kedua aktivitas itu harus saling berkaitan. Lebih lanjut lagi piaget menerangkan dalam buku Sardiman bahwa jika seorang anak berfikir tanpa berbuat sesuatu, berarti anak itu tidak berfikir (Sardiman, 2011:100).

Nanang Hanafiah dan Cucu Suhana (2010:24) menjelaskan bahwa aktivitas belajar dapat memberikan nilai tambah (added value) bagi peserta didik, berupa halhal berikut ini:

1. Peserta didik memiliki kesadaran (awareness) untuk belajar sebagai wujud adanya aktivitas internal untuk belajar sejati.

2. Peserta didik mencari pengalaman dan langsung mengalami sendiri, yang dapat memberikan dampak terhadap pembentukan pribadi yang integral.

3. Peserta didik belajar dengan menurut minat dan kemampuannya.

4. Menumbuh kembangkan sikap disiplin dan suasana belajar yang demokratis di kalangan peserta didik.

5. Pembelajaran dilaksanakan secara konkret sehingga dapat menumbuh kembangkan pemahaman dan berfikir kritis serta menghindarkan terjadinya verbalisme.

6. Menumbuh kembangkan sikap kooperatif dikalangan peserta didik sehingga sekolah menjadi hidup, sejalan dan serasi dengan kehidupan di masyarakat di sekitarnya.

Dalam penelitian ini yang dimaksud dengan aktivitas belajar adalah kegiatan peserta didik mengingat, memecahkan 
masalah, menganalisis faktor-faktor, melihat hubungan-hubungan, dan membuat keputusan terhadap masalah yang diberikan oleh guru kelas V di SD Negeri 47 Cakranegara.

\section{Hasil Belajar}

Masalah belajar adalah masalah bagi setiap manusia, dengan belajar manusia memperoleh keterampilan, kemampuan sehingga terbentuklah sikap dan bertambahlah ilmu pengetahuan. Jadi hasil belajar itu adalah suatu hasil nyata yang dicapai oleh peserta didik dalam usaha menguasai kecakapan jasmani dan rohani di sekolah yang diwujudkan dalam bentuk raport pada setiap semester.

Untuk mengetahui perkembangan sampai di mana hasil yang telah dicapai oleh seseorang dalam belajar, maka harus dilakukan evaluasi. Untuk menentukan kemajuan yang dicapai maka harus ada kriteria (patokan) yang mengacu pada tujuan yang telah ditentukan sehingga dapat diketahui seberapa besar pengaruh strategi belajar mengajar terhadap keberhasilan belajar peserta didik. Hasil belajar peserta didik menurut W. Winkel (dalam buku Psikologi Pengajaran 1989:82) adalah keberhasilan yang dicapai oleh peserta didik, yakni prestasi belajar peserta didik di sekolah yang mewujudkan dalam bentuk angka.

Untuk mengetahui tercapai tidaknya tujuan pembelajaran khusus, guru perlu mengadakan tes formatif pada setiap menyajikan suatu bahasan kepada peserta didik. Penilaian formatif ini untuk mengetahui sejauh mana peserta didik telah menguasai tujuan pembelajaran khusus yang ingin dicapai. Fungsi penelitian ini adalah untuk memberikan umpan balik pada guru dalam rangka memperbaiki proses belajar mengajar dan melaksanakan program remedial bagi peserta didik yang belum berhasil. Karena itulah, suatu proses belajar mengajar dinyatakan berhasil apabila hasilnya memenuhi tujuan pembelajaran khusus dari bahan tersebut.

Dalam penelitian ini yang dimaksud dengan hasil belajar adalah laporan individu dan tes dalam bentuk tertulis yang materi soalnya hanya selintas apa yang disajikan oleh guru selama prose pembelajaran di kelas.
Dalam hal ini adalah materi pembelajaran Pendidikan Agama Islamkelas V.

\section{Model STAD}

STAD merupakan salah satu metode pembelajaran kooperatif yang paling sederhana yang merupakan modul yang paling baik untuk perencanaan bagi para guru yang menggunakan pendekatan cooperative (Robert E. Slavin, 2010:143). Student Teams Archievent Divisions (STAD) terdiri dari lima komponen utama yaitu: 1) presentasi kelas, 2) Tim, 3) kuis, 4) Skor kemajuan individu, dan 5) Rekognisi Tim.

Presentasi kelas. Materi dalam STAD pertama-tama diperkenalkan dalam presentasi di dalam kelas. Ini merupakan pengajaran langsung seperti yang sering dilakukan atau diskusi pelajaran yang dipimpin oleh guru, tetapi bisa juga memasukkan presentasi audiovisual. Bedanya Presentasi Kelas dengan pengajaran biasa hanyalah bahwa presentasi tersebut haruslah benar-benar berfokus pada unit STAD. Dengan cara ini, para Peserta didik akan menyadari bahwa mereka harus benar-benar memberikan perhatian penuh selama presentasi kelas, karena dengan demikian akan sangat membantu mereka mengerjakan kuis-kuias, dan skor kuis mereka menentukan skor tim mereka.

Tim. Tim terdiri dari empat atau lima Peserta didik yang mewakili seluruh bagian dari kelas dalam hal kinerja akademik, jenis kelamin, ras dan etnisitas. Fungsi utama dari tim ini adalah memastikan bahwa semua anggota tim benar-benar belajar, dan lebih khususnya lagi, adalah untuk mempersiapkan anggotanya untuk bisa mengerjakan kuis dengan baik. Setelah guru menyampaikan materinya, tim berkumpul untuk mempalajari lembar kegiatan atau materi lainnya. Yang paling sering terjadi, pelajaran itu melibatkan pembahasan permasalah bersama, membandingkan jawaban, dan mengoreksi tiap kesalahan pemahaman apabila anggota tim ada yang membuat kesalahan.

Tim adalah fitur yang paling penting dalam STAD. Pada tiap poinnya, yang ditekankan adalah membuat anggota tim melakukan yang terbaik untuk tim, dan tim pun harus melakukan yang terbaik untuk membantu tiap anggotanya. Tim ini 
memberikan dukungan kelompok bagi kinerja akademik penting dalam pembelajaran, dan itu adalah untu memberikan perhatian dan respek yang mutual yang penting untuk akibat yang dihasilkan seperti hubungan antarkelompok, rasa harga diri, penerimaan terhadap Peserta didik-Peserta didikmainstream.

Kuis. Setelah sekitar satu atau dua periode setelah guru memberikan presentasi dan sekitar satu atau dua periode praktik tim, para Peserta didik akan mengerjakan kuis individual. Para iswa tidak diperbolehkan untuk saling membantu dalam mengerjakan kuis. Sehingga, tiap Peserta didik bertanggung jawab secara individual untuk memahami materinya.

Skor Kemajuan Individual. Gagasan dibalik skor kenmajuan individual adalah untuk memberikan kepada tiap Peserta didik tujuan kinerja yang dapat dicapai apabila mereka bekerja lebih giat dan memberikan kinerja yang lebih baik daripada sebelumnya. Tiap Peserta didik dapat memberikan kontribusi poin yang maksimal kepada timnya dalam sistem skor ini, tetapi tidak ada Peserta didik yang dapat melakukannya tanpa memberikan usaha mereka yang terbaik. Tiap Peserta didik diberikan skor "awal", yang diperoleh dari rata-rata kinerja Peserta didik tersebut sebelumnya dalam mengerjakan kuis yang sama. Peserta didik selanjutnya akan mengumpulkan poin untuk tim mereka berdasarkan tingkat kenaikan skor kuis mereka dibandingkan dengan skor awal mereka.

Rekognisi Tim. Tim akan mendapatkan sertifikat atau bentuk penghargaan yang lain apabila skor rata-rata mereka mencapai kriteria tertentu. Skor tim Peserta didik dapat juga digunakan untuk menentukan dua puluh persen dari peringkat mereka.

\section{Hipotesis Tindakan}

"Penerapan Model STAD dapat meningkatkan aktivitas dan hasil belajar peserta didik kelas V SD Negeri 47 Cakranegara semester dua Tahun pelajaran 2018/2019".

\section{PROSEDUR PENELITIAN Setting Penelitian}

Penelitian tindakan kelas (PTK) ini akan dilaksanakan di kelas V SD Negeri 47 Cakranegarasemester duatahun pelajaran 2018/2019, dengan jumlah peserta didik sebanyak 23 orang.

\section{Faktor yang Diteliti}

1. Faktor Guru: yaitu dengan mengamati cara guru membuat Rencana Pelaksanaan Pembelajaran (RPP) dan pelaksanaannya dalam pembelajaran di kelas senyatanya dengan menerapkan Model STAD dalam upaya meningkatkan aktivitas dan hasil belajar Pendidikan Agama Islam peserta didik Kelas VSD Negeri 47 Cakranegara.

2. Faktor Peserta didik: yaitu peningkatan aktivitas belajar peserta didik yang terlihat pada saat melaksanakan diskusi kelompok, dan pada saat tes tertulis di akhir pembelajaran bagi peserta didik kelas V Semester dua Tahun pelajaran 2018/2019 di SD Negeri 47 Cakranegara.

\section{Rencana Tindakan}

kegiatan nyata di kelas $\mathrm{V}$ yaitu melaksanakan proses pembelajaran dengan menerapkan Model STAD dalam upaya meningkatan aktivitas dan hasil belajar Pendidikan Agama Islam peserta didik kelas VSD Negeri 47 Cakranegara semester dua tahun pelajaran 2018/2019. Tindakan nyata yang dilakukan oleh guru selaku peneliti adalah dengan menggunakan siklus. Gambaran siklus dalam penelitian ini adalah sebagai berikut:



Setiap siklus selama penelitian ini berisi 4 (empat) tahapan yaitu: 1) Perencanaan (Planning), 2) Pelaksanaan (Action), 3) 
Observasi (Observation), dan 4) Refleksi (Reflection).

\section{Siklus Tindakan}

\section{SIKLUS I}

\section{Tahap Perencanaan (Planning)}

1. Menyusun Rencana Pelaksanaan Pembelajaran (RPP) dengan skenario sesuai dengan aturan main model STAD.

2. Menyiapkan sumber, bahan, dan semua alat yang digunakan dalam penelitian.

3. Menyusun/membuat lembar observasi guru dan lembar observasi Peserta didik.

4. Menyusun alat evaluasi.

\section{Tahap Pelaksanaan (Action)}

\section{Pertemuan I}

1. Guru membagi Peserta didik menjadi 6 (enam) kelompok kecil, masing-masing kelompok beranggotakan 3-4 orang Peserta didik.

2. Masing-masing kelompok diberikan tugas/soal untuk dipecahkan bersama dalam kelompok.

\section{Pertemuan II}

3. selanjutnya melaksanakan 5 (lima) komponen utama STAD yaitu : 1) Presentasi Kelas, 2) Tim, 3) Kuis, 4) Skor kemajuan individual, dan 5) Rekognisi Tim.

4. Tes tertulis

Tahap Observasi (Observation)

1. Observasi guru :Dilakukan oleh pengawas/observer sekaligus sebagai pembimbing guru dalam melaksanakan Penelitian Tindakan Kelas (PTK).

2. Observasi Peserta didik : Dilaksanakan oleh guru mata pelajaran sekaligus sebagai peneliti dalam Penelitian Tindakan Kelas (PTK) pada kegiatan diskusi kelompok.

\section{Tahap Refleksi (Reflection)}

1. Renungan hasil perolehan data

2. Pengolahan dan analisa data hasil penelitian

3. Mencocokkan hasil analisa data dengan indikator keberhasilan

4. Rencana perbaikan dan tindak lanjut

SIKLUS II

Pada siklus ini semua kegiatan dan tahapan selama penelitian adalah sama, sifatnya mengulang dan memperbaiki terhadap tindakan yang masih memerlukan penyempurnaan dan pembenaran sebagaimana mestinya.

\section{Data dan Cara Pengambilannya.} Sumber Data

Yang menjadi sumber data dalam penelitian tindakan kelas (PTK) ini adalah semua peserta didikkelas VSD Negeri 47 Cakranegara semester duatahun pelajaran 2018/2019 dan guru kelas/mata pelajaran Pendidikan Agama Islam.

\section{Jenis Data}

- Jenis data yang berasal dari guru selaku peneliti

1). Data tentang Rencana Pelaksanaan Pembelajaran (RPP)

2). Data Pelaksanaan Pembelajaran

- Jenis data yang berasal dari peserta didik :

1). Data kemajuan aktivitasbelajar

2). Data hasil laporan individu hasil diskusi kelompok

3). Data hasil belajar peserta didik/tes tertulis

\section{Cara Pengambilan data}

- Data kegiatan pembelajaran diambil dari RPP yang dibuat oleh guru dan lembar observasi pelaksanaan model STAD

- Data kemajuan aktivitas belajar; diambil dari lembar observasi selama kerja kelompok dan presentasi kelompok.

- Data kemajuan hasil belajar; diambil dari laporan hasil kerja kelompok secara individual dan nilai hasil tes tertulis yang dilaksanakan pada akhir proses pembelajaran

\section{Indikator Keberhasilan dan Teknik analisa data}

Teknik analisa data

Untuk menganalisis data akan dilakukan melalui analisis deskriptif kuantitatif melalui pendataan, analisis dan pembahasan terhadap data yang diperoleh dengan mencocokkan tingkat keoptimalan terhadap capaian indikator keberhasilan yang ada.

\section{Indikator Keberhasilan}

1. guru telah dinyatakan berhasil melaksanakan proses pembelajaran dengan pendekatan penerapan model STAD, bila telah mencapai skor rata-rata $>4,00$ 
2. aktivitasbelajar Pendidikan Agama Islam peserta didik kelas Vdinyatakan telah meningkat jika $\geq 85 \%$ dari jumlah peserta didik telah memperoleh skor rata-rata $\geq$ 4,0 (kategori baik) dan hasil belajar dinyatakan telah meningkat jika $\geq 85 \%$ dari jumlah peserta didik memperoleh nilai rata-rata $\geq 75,00(\mathrm{KKM}$ Peserta didik).

\section{HASIL PENELITIAN DESKRIPSI SIKLUS I}

\section{Tahap Perencanaan}

Pada tahapan ini yang telah dilakukan oleh guru selaku peneliti adalah; 1) menyusun RPP dengan skenario pembelajaran ModelSTAD, 2) telah berhasil menyiapkan alat, sumber, bahan yang diperlukan dalam penelitian, 3) berhasil menyusun instrument observasi guru dan instrument observasi peserta didik, dan 4) menyusun alat evaluasi.

\section{Tahap Pelaksanaan}

a. Guru membagi Peserta didik dalam TIM, yang keanggotaannya secara heterogen dengan harapan dalam satu tim ada yang pintar, sedang dan ada yang kurang. Pembauran agama, ras dan suku agar dalam tim benar-benar heterogen dan berbhineka tunggal ika.

b. Guru menyampaikan materi pelajaran dengan berbagai strategi, kemudian memberikan tugas kepada semua tim untuk dibagikan secara kelompok (mengerjakan kuis)

c. Guru memberikan skor kemajuan individual selama kerja kelompok dalam mengerjakan kuis yang menjadi tanggung jawab tim (kelompok).

d. Rekognisi tim yaitu guru memberikan penghargaan kepada tim atau secara individual apabila hasil kerjanya sudah mencapai criteria yang telah ditetapkan oleh guru.

a. Selama kerja kelompok dari tahap tim, kuis, skor kemajuan individual, dan rekognisi tim guru melakukan penyeimbangan peningkatan/kemajuan motivasi dan hasil belajarPeserta didik yang meliputi aspek antusias, kerjasama, aktivitas, kemampuan menjawab, dan efektifitas waktu dan hasil tes tertulis

\section{Tahap Observasi}

Observasi guru memperoleh skor rata-rata sebesar 3,21 dan 3,57, observasi peserta didik memperoleh skor rata-rata sebesar 3,39 dan 3,61 , hasil belajar peserta didik diambil dari nilai tugas dan tes tertulis memperoleh nilai rata-rata sebesar 69,74 dan 64,35

\section{Tahap Refleksi}

1. Renungan data hasil perolehan data pada siklus I

2. Pengolahan data hasil observasi guru, peserta didik dan tes tertulis.

3. Mencocokkan hasil yang ada dengan Indikator keberhasilan.

4. Merencanakan perbaikan terhadap jenis tindakan yang menyebabkan belum tuntas Indikator keberhasilan. Oleh karena Indikator keberhasilan belum terbukti maka penelitian dilanjutkan ke siklus II.

\section{DESKRIPSI SIKLUS II}

\section{Tahap Perencanaan}

Pada tahapan ini jenis kegiatan yang dilakukan masih mengacu pada kegiatan siklus I, bedanya hanya terjadi perbaikan seperlunya yaitu: 1) penyusunan RPP dengan mengacu pada penerapan model STAD dan penyempurnaan pada bagian skenario pembelajaran, 2) menyiapkan alat, sumber, bahan yang diperlukan dalam proses tindakan dikelas senyatanyan, 3) menyiapkan lembar observasi guru dan lembar observasi peserta didik sebagaimana pada siklus I, 4) menyiapkan alat evaluasi sebagaimana yang telah dibuat pada siklus I.

\section{Tahap Pelaksanaan}

Secara umum tahapan pelaksanaan proses pembelajaran pada siklus II ini masih mengacu pada pelaksanaan proses pembelajaran sebelumnya. Yang dilakukan pada proses pembelajaran ini adalah: 1) pelaksanaan proses diskusi kelompok kecil lebih dioptimalkan, 2) pelaksanaan pembimbingan kelompok sekaligus observasi peserta didik lebih di efektifkan. Utamanya pengamatan peserta didik yang aktif, yang kurang aktif, peserta didik yang tidak aktif, dengan harapan proses analisa data lebih signifikan, 3)laporan hasil kerja kelompok yang dibuat secara individu lebih difokuskan, dan 4) pelaksanaan tes tertulis sebagai tolak 
ukur keberhasilan peserta didik lebih dioptimalkan.

\section{Tahap Observasi}

Observasi guru memperoleh skor rata-rata sebesar 4,29 dan 4,64, observasi peserta didik memperoleh skor rata-rata sebesar 4,35 dan 4,74, hasil belajar peserta didik diambil dari nilai tugas dan tes tertulis memperoleh nilai rata-rata sebesar 82,04 dan 80,96

\section{Tahap Refleksi}

1. Renungan atas perolehan data hasil observasi guru, observasi peserta didik, dan hasil tes tertulis sebagai hasil dari peningkatan aktivitas dan hasil belajar peserta didik di kelas senyatanya.

2. Pengolahan data hasil observasi guru, observasi peserta didik dan tes tertulis

3. Mencocokkan perolehan data hasil tindakan dengan Indikator keberhasilan yang telah ditetapkan.

4. Guru memberikan hadiah/reward kepada semua peserta didik kelas $\mathrm{V}$ atas keberhasilannya dalam upaya meningkatkan aktivitas dan hasil belajar dan perolehan hasil belajar sesuai dengan KKM yang telah ditetapkan.

\section{PEMBAHASAN}

\section{SIKLUS I}

\section{Tahap Perencanaan}

Dalam tahapan ini, beberapa kendala dihadapi oleh peneliti dalam mempersiapkan segala materi yang berkaitan dengan pendampingan. Namun setelah meminta petunjuk dan berkonsultasi kepada pembimbing, kendala yang dihadapi dapat diatasi dengan baik dan kegiatan pendampingan pun dapat berjalan sesuai dengan yang diharapkan.

\section{Tahap Pelaksanaan}

a. TIM: guru membagi Peserta didika menjadi enam tim (kelompok), masingmasing beranggotakan 3-4 orang. Kegiatan selanjutnya guru memberikan materi pelajaran dengan menggunakan berbagai strategi/tipe yang intinya Peserta didik bisa menyerap dan memahaminya.

b. Kuis: setelah guru selesai menyampaikan materi pelajaran, setiap Peserta didik mengerjakan soal (kuis) secara individu didalam kelompoknya. Para Peserta didik tidak boleh bekerjasama satu sama lain, karenanya guru berkeliling untuk mengamati agar Peserta didik memiliki tanggung jawab dalam memecahkan soal yang sudah disiapkan oleh guru dalam bentuk lembar kerja Peserta didik (LKS).

c. Skor kemajuan individual: pada kegiatan ini guru memberikan apresiasi kepada setiap Peserta didik yang bekerja lebih giat serta bekerja lebih baik bila dibandingkan sebelumnya. Bagi Peserta didik yang banyak memberikan kontribusi kepada kelompok (tim) diberikan poin sesuai dengan tingkat kebenarannya, begitu seterusnya.

d. Rekognisi tim: tim (kelompok) akan mendapat sertifikat/penghargaan apabila perolehan skor rata-rata mereka mencapai criteria yang telah ditentukan oleh guru IPA, PPKn, dan Pendidikan Agama Islam.

Kegiatan pembelajaran diakhiri dengan tes tertulis, hal ini dimaksudkan untuk mengetahui dampak positif dari peningkatan aktivitasdan hasil belajar Pendidikan Agama Islam Peserta didik Kelas VSD Negeri 47 Cakranegara semester Dua tahun pelajaran 2018/2019 dengan penerapan model STAD. Asumsi bila aktivitas dan hasil belajar meningkat maka akan berdampak meningkatnya hasil belajar Peserta didik.

\section{Tahap Observasi}

Observasi guru memperoleh skor ratarata pertemuan I $(3,21)$ dan pertemuan II $(3,57)$, Hasil observasi peserta didik dalam upaya peningkatan aktivitas dan hasil belajar Pendidikan Agama Islam peserta didik kelas V semester dua tahun pelajaran 2018/2019 di SD Negeri 47 Cakranegara diperoleh skor rata-rata pertemuan I $(3,39)$ dan pertemuan II $(3,61)$. Perolehan nilai rata-rata tugas individual dan tes tertulis yang dilakukan pada akhir pelajaran adalah $(69,74)$ dan $(64,35)$.

\section{Tahap Refleksi}

Hasil analisa data perolehanaktivitas dan hasil belajar pada siklus I ini $(3,50)$ sedangkan yang diminta dalam Indikator keberhasilan $(\geq 4,0)$, ini artinya belum berhasil.

Karena Indikator keberhasilan belum tercapai, penelitian tindakan kelas (PTK) 
dilanjutkan ke siklus II dengan harapan optimalisasi penerapan model STAD dapat meningkatkan aktivitas dan hasil belajar Pendidikan Agama Islam peserta didik kelas V semester dua tahun pelajaran 2018/2019 di SD Negeri 47 Cakranegara.

\section{SIKLUS II}

\section{Tahap Perencanaan}

Peneliti menyusun Rencana

Pelaksanaan Pembelajaran (RPP) dengan memperhatikan kesalahan-kesalahan pada siklus I. peneliti lebih memfokuskan tentang Rencana strategi jitu sehingga proses pembelajaran dengan model STAD dapat terelaisasi dengan baik, karenanya dalam penyusunan skenario benar-benar dirinci dari tiap aspek pada proses pembelajaran dengan STAD.

Sebelum proses pembelajaran dilaksanakan, peneliti menyiapkan semua alat, bahan, dan segala sesuatunya sehingga dalam pelaksanaan proses pembelajaran berjalan sesuai dengan skenario yang telah direncanakan. Agar proses pembelajaran dapat teratasi maka peneliti juga menyiapkan lembar observasi guru dan lembar observasi peserta didik sebagai tolak ukur ketercapaian peningkatan aktivitas dan hasil belajar Pendidikan Agama Islam peserta didik kelas VSD Negeri 47 Cakranegara.

\section{Tahap Pelaksanaan}

Pada tahap pelaksanaan di siklus II ini pada dasarnya masih mengacu pada pelaksanaan siklus I, yaitu penerapan model STAD. Bedanya pada siklus ini lebih dioptimalkan.

\section{Tahap Observasi}

Pada siklus II ini hasil observasi memperoleh skor rata-rata pertemuan I $(4,29)$ dan Pertemuan II $(4,64)$, Upaya meningkatkan aktivitas dan hasil belajar Pendidikan Agama Islampeserta didikkelas Vsemester duatahun pelajaran 2018/2019 di SD Negeri 47 Cakranegara diperoleh skor rata-rata pertemuan I $(4,35)$ dan pertemuan II $(4,74)$, Dampak nyata dari meningkatnya aktivitas dan hasil belajar adalah prestasi belajar juga meningkat, dari data hasil perolehan nilai rata-rata nilai tugas dan tes tertulis adalah $(82,04)$ dan $(80,96)$ ini berarti mengalami peningkatan yang signifikan.

\section{Tahap Refleksi}

Hasil analisa data peningkatan aktivitas dan hasil belajar peserta didik pada siklus II adalah (4,55) sedangkan Indikator keberhasilan $(\geq 4,0)$. Ini artinya pada siklus II hasilnya telah melampaui Indikator keberhasilan. Hasil belajar pada siklus I $(67,05)$ sedangkan pada siklus II $(81,50)$, ini artinya indikator keberhasilan telah dilampaui.

Karena Indikator keberhasilan telah terbukti, maka tidak perlu ada upaya perbaikan dan penyempurnaan. Penerapanm model STAD telah mampu meningkatkan aktivitas dan hasil belajar peserta didik yang ditandai dengan tercapainya Indikator keberhasilan dan terjadinya peningkatan hasil belajar peserta didik. "Penelitian Tindakan Kelas (PTK) dihentikan pada siklus II dengan hasil memuaskan."

\section{SIMPULAN}

Data komulatif dari hasil penelitian tindakan kelas (PTK) dari siklus I ke Siklus II adalah sebagai berikut:

\begin{tabular}{|c|c|c|c|c|c|c|c|}
\hline \multirow{2}{*}{ No } & \multirow{2}{*}{ Jenis Keggiatan } & \multirow{2}{*}{$\begin{array}{l}\text { Indikator } \\
\text { Keberhasilan }\end{array}$} & \multicolumn{2}{|c|}{ Siklus I } & \multicolumn{2}{|c|}{ Siklus II } & \multirow{2}{*}{ Ket } \\
\hline & & & $\mathrm{A}$ & $B$ & $\mathrm{~A}$ & $B$ & \\
\hline 1. & Hasil Observaasi Guru & $\geq 4,00$ & 3,21 & 3,57 & 4,29 & 4,64 & Tuntas \\
\hline 2. & Observasi Pesenta didik & $\geq 4,00$ & 3,39 & 3,61 & 4,35 & 4,74 & Tuntas \\
\hline 3. & $\begin{array}{l}\text { Hasil Laporan tugas kel. } \\
\text { secara individual }\end{array}$ & $\geq 75,00$ & 69, &, 74 & 82 & 04 & Tuntas \\
\hline 4. & Hasil Tes tertulis & $\geq 75,00$ & 64, & & 80 & 96 & Tuntas \\
\hline
\end{tabular}

Penerapan model STAD sangat efektif dalam upaya untuk meningkatkan aktivitas dan hasil dan hasil belajar Pendidikan Agama Islampeserta didikkelas Vsemester duatahun pelajaran 2018/2019 di SD Negeri 47 Cakranegara. Fakta telah menunjukkan perolehan rata-rata skor aktivitas dan hasil belajar peserta didik pada siklus I $(3,50)$, sedangkan pada siklus II $(4,55)$, hasil belajar dari 67,05 menjadi 81,50sudah melampaui Indikator keberhasilan yang ditetapkan. Penelitian dinyatakan "berhasil" dan dihentikan pada siklus II.

\section{SARAN}

Disarankan kepada guru sejawat untuk melaksanakan Penelitian Tindakan Kelas (PTK) dalam upaya untuk meningkatkan 
aktivitas dan hasil dan hasil belajar peserta didik sesuai dengan mata pelajaran masingmasing.

Disarankan kepada para semua peserta didik kelas VSD Negeri 47 Cakranegara untuk membiasakan belajar dengan pendekatan yang kontekstual utamanya strategi yang mampu membangkitkan aktivitas dan hasil dan hasil belajar peserta didik yang dampaknya prestasi belajar dapat ditingkatkan seperti yang diharapkan.

\section{DAFTAR PUSTAKA}

Anonim, 2019, dalam https://ekokhoerul.wordpress.com/201 2/06/27/konsep-aktivitas-belajarsiswa/, diambil tanggal 6 Januari 2019, pukul 13.46 Wita.

Anonim, 2019, dalam http://ainamulyana.blogspot.co.id/201 2/01/pengertian-hasil-belajar-danfaktor.html, diambil tanggal 6 Januari 2019, Pukul 14.54 Wita

Al Hakim, S dan Riyanto, M, 2002, strategi Pembelajaran Berdasarkan Deep Dialogue/Critical Thinking (DD/CT), Malang: PPPG IPS dan PMP

Arikunto, s. 2009, Penelitian Tindakan Kelas, Jakarta : Bumi Aksara.

Harun Rasyid dan Mansur, 2008, Penilaian Hasil Belajar, Bandung : CV Wacana Prima.

Lie, A, 2002, Cooperative Learning, Jakarta: Gramedia Widiasarma Indonesia.

Lukmanul A, 2008, Perencanaan Pembelajaran, Bandung : CV Wacana Prima.

Mukhtar, 2003, Prosedur Penilaian, Jakarta : Rineka Cipta.

Nurhadi, 2003, Yasin ,B dan Sendule.A, 2003, Kontekstual dan Penerapannya dalam KBK, Malang : Unitipetas Negeri Malang.

Robert E Slavin, 2010, Cooperative Learning Teori, riset dan Praktik, Bandung : Nusa Media.

Sardiman, 2007, Indikator Dan Aktivitas dan hasil Belajar Mengajar, Jakarta : Raja Grafindo Perkasa.

Supriono, 2009, Cooperative Learning Teori dan Aplikasi PAIKEM, Yogyakarta : Pustaka Pelajar. 